Review

\title{
Suppression of NADPH Oxidase Activity May Slow the Expansion of Osteolytic Bone Metastases
}

\author{
Mark F. McCarty * and James DiNicolantonio \\ Catalytic Longevity, 7831 Rush Rose Dr, Apt 316, Carlsbad, CA 92009, USA; jjdinicol@gmail.com \\ * Correspondence: markfmccarty@catalyticlongevity.org; Tel.: +1-760-216-7272; Fax: +1-760-704-6379 \\ Academic Editor: Sampath Parthasarathy \\ Received: 19 July 2016; Accepted: 22 August 2016; Published: 25 August 2016
}

\begin{abstract}
Lysophosphatidic acid (LPA), generated in the microenvironment of cancer cells, can drive the proliferation, invasion, and migration of cancer cells by activating $G$ protein-coupled LPA receptors. Moreover, in cancer cells that have metastasized to bone, LPA signaling can promote osteolysis by inducing cancer cell production of cytokines, such as IL-6 and IL-8, which can stimulate osteoblasts to secrete RANKL, a key promoter of osteoclastogenesis. Indeed, in cancers prone to metastasize to bone, LPA appears to be a major driver of the expansion of osteolytic bone metastases. Activation of NADPH oxidase has been shown to play a mediating role in the signaling pathways by which LPA, as well as RANKL, promote osteolysis. In addition, there is reason to suspect that Nox4 activation is a mediator of the feed-forward mechanism whereby release of TGF-beta from bone matrix by osteolysis promotes expression of PTHrP in cancer cells, and thereby induces further osteolysis. Hence, measures which can down-regulate NADPH oxidase activity may have potential for slowing the expansion of osteolytic bone metastases in cancer patients. Phycocyanin and high-dose statins may have utility in this regard, and could be contemplated as complements to bisphosphonates or denosumab for the prevention and control of osteolytic lesions. Ingestion of omega-3-rich flaxseed or fish oil may also have potential for controlling osteolysis in cancer patients.
\end{abstract}

Keywords: lysophosphatidic acid; osteolysis; NADPH oxidase; TGF-beta, phycocyanin; statins

\section{A Role for Lysosphosphatidic Acid Signaling in Generation of Osteolytic Metastases}

Generation of lysophosphatidic acid (LPA) in the microenvironment of cancer cells has emerged as an important driver of the expansion of osteolytic metastases [1]. Many cancer cells express G protein-coupled receptors of the EDG family-LPA1, LPA2, and LPA3 - which can be activated by various isoforms of LPA [2]. LPA1 is the most widely expressed LPA receptor, it has the broadest specificity for forms of LPA, and it has received the most research attention to date [3]. Activation of these receptors can promote cellular proliferation and invasiveness, and can also stimulate osteolytic activity in bone [4,5].

Some cancer cells provoke local generation of LPA by triggering aggregation of nearby platelets [6]. Aggregating platelets generate large amounts of lysophosphatidylcholine (LPC), and serum contains modest amounts of a special phospholipase D activity that specifically targets LPC - known as "autotaxin"-which converts LPC to LPA by removing the choline head group [7,8]. Hence, LPA is generated in the microenvironment of aggregated platelets, and can act on cancer cells that have provoked this aggregation. Alternatively, plasma contains meaningful amounts of LPC, reflecting systemic platelet activation, and many cancer cells make and secrete autotaxin, which can convert plasma LPC to LPA near the cell surface [8,9]. Another enzyme produced by some cancer cells that can generate LPA is acylglycerol kinase, which acts on the monoacylglycerol in plasma [10,11]. In prostate cancer patients, the extent to which their cancers expressed autotaxin, but not acylglycerol kinase, correlated positively with risk for biochemical recurrence following surgery [10]. 
Activation of the EDG family LPA receptors, via heterotrimeric G proteins, promotes activation of diverse signaling pathways, including Akt, RhoA, NF-kappaB, and ERK1/2 [12-14]. These pathways can promote proliferation, invasion, and migration, and also, by stimulating the transcriptional activity of AP-1 and NF-kappaB, induce expression of certain cytokines, including IL-6 and IL-8 $[6,15,16]$. When cancer cells have metastasized to bone, secreted IL-6 and IL- 8 can act on neighboring osteoblasts to provoke secretion of RANKL, which in turn can act on macrophages/monocytes to promote their differentiation to osteoclasts [6,9]. The resulting osteolysis tends to release growth factors from the bone matrix-TGF-beta, IGF-I, calcium ions-that provide a further growth stimulus to neighboring cancer cells, in a positive feedback loop [17]. Hence, cancer cells sited in bone that are capable of generating LPA receive a further growth stimulus while causing breakdown of local bone matrix, such that bone tends to be replaced by expanding metastases [18]. Clinical consequences can include severe pain (provoked in part by the acid released during osteolysis), fractures, nerve compression, and hypercalcemia.

\section{NADPH Oxidase Is a Mediator of both LPA and RANKL Signaling}

There is evidence that the signaling pathways stimulated by LPA1, as well as by RANKL, are dependent on activation of NADPH oxidase complexes. Working with PC3 prostate cancer and SKOV3 ovarian cancer, which express LPA1 and are LPA responsive, Daniel and colleagues have shown that the NADPH oxidase inhibitors DPI and apocynin, as well as the antioxidants $\mathrm{N}$-acetylcysteine and PEG-catalase, suppress LPA-mediated activation of Akt, ERK, and NF-kappaB $[19,20]$. Further analysis has indicated that interaction of LPA with LPA1 induces internalization of the complex into early endosomes, following by assemblage and activation of an NADPH oxidase complex affiliated with the endosome that generates hydrogen peroxide within it. This hydrogen peroxide then oxidizes cysteine residues, forming sulfenyl groups, in certain neighboring enzymes, including Akt2 and the tyrosine phosphatase PTP1B. This oxidizing activity presumably is a prerequisite for the downstream activation of LPA1's key targets, since NADPH oxidase inhibitors, as well as catalase and N-acetylcysteine (capable of reversing sulfenic acid formation), block this activation [20]. A study in PC3 cells demonstrates that sequential activation of PLC and PKC mediates LPA-induced NADPH oxidase activation [21].

Moreover, the RANKL-induced promotion of macrophage differentiation into osteoclasts is also dependent on activation of NADPH oxidase activity, as DPI and $\mathrm{N}$-acetylcysteine block this differentiation [22,23]. Traf6 and Rac1 are required for NADPH oxidase activation, and the Nox1, Nox2, and Nox4-dependent complexes are involved. Although Nox2 is the form of NADPH oxidase most highly expressed in macrophages, RANKL stimulation downregulates Nox2, and up-regulates Nox1 and $4[24,25]$.

\section{A Role for Nox4 in TGF-beta-Driven Osteolysis}

NADPH oxidase activity-specifically, Nox4-may play a role in an additional prominent mechanism, whereby bone metastases promote osteolysis. TGFbeta, released from degraded bone matrix, can induce cancer cells to produce parathyroid hormone-related peptide (PTHrP) [26-30]. This is turn can stimulate osteoblasts to produce RANKL, and suppress their production of the RANKL antagonist osteoprotegerin-thereby activating osteoclastogenesis [31-34]. Hence, this represents a feed forward mechanism whereby osteolysis can promote further osteolysis. There is reason to suspect that Nox4 induction and activation is required for the efficient induction of PTHrP by TGF-beta. TGF-beta signaling typically entails induction and activation of Nox4 [35-38].

The mechanism by which TGF-beta induces PTHrP in MDA-MB-231 breast cancer cells has been partially defined [30]. Activation of SMAD signaling, as well as of p38 MAP kinase, collaborate in inducing transcription of the PTHrP gene; the authors refer to p38 as "a new target for osteolytic therapy". In other contexts, activation of p38 MAP kinase by TGF-beta has been shown to be dependent on Nox4 activation [39-42]. For example, in TGF-beta-treated mouse embryo fibroblasts, knock-down 
of Nox4 suppresses p38 MAP kinase activation [39]. This reflects the fact that Nox4 activity is capable of inhibiting MAPK phosphatase 1 (MKP-1) by reversibly oxidizing a key cysteine group in this enzyme. Within the nucleus, MKP-1 functions to dephosphorylate and thereby inactivate the p38 and JNK MAP kinases, and hence its inhibition by Nox4 activity up-regulates p38 MAP kinase signaling [39]. In fibroblasts treated with TGF-beta, Nox4 translocated to the nucleus, and MKP-1 activity was reduced by about $50 \%$.

Hence, there appear to be at least 3 signaling pathways involved in LPA-stimulated osteolysis-those triggered by LPA, RANKL, and TGF-beta-in which NADPH oxidase activation plays a mediating role. It therefore seems reasonable to propose that measures capable of safely down-regulating NADPH oxidase activation or activity could have potential for slowing the expansion of LPA-driven bone metastases.

\section{Potential Utility of Phycocyanin and High-Dose Statins as NADPH Oxidase Inhibitors}

The profound antioxidant activity of the free bilirubin generated within cells by heme oxygenase activity has been traced to inhibition of NADPH oxidase complexes; the isoform-specificity of this effect requires further clarification, although Nox2 and Nox4 appeared to be targeted [43-47]. The fact that elevated serum levels of free bilirubin are associated in prospective epidemiology with a range of favorable health outcomes [48-53] — most notably, that individuals with Gilbert syndrome enjoy a 50\% reduction in total age-adjusted mortality [54] - suggests that moderate systemic down-regulation of NADPH oxidase activity can be safe and indeed protective in various respects.

Phycocyanin, a key protein in cyanobacteria such as spirulina (constituting up to $20 \%$ of its dry mass), and also produced in some eukaryotic algae, is noted for its outstanding antioxidant and anti-inflammatory activity in rodent and cell culture studies; this activity appears to stem from its covalently-attached chromophore, phycocyanobilin (PhyCB) [55,56]. PhyCB is a metabolite of biliverdin, and within cells biliverdin reductase activity can convert it to phycocyanorubin, very similar in structure to bilirubin [57]. Indeed, exposure of human cells to either biliverdin or PhyCB results in dose-dependent inhibition of NADPH oxidase activity, likely mediated by bilirubin and phycocyanorubin, respectively [56,58]. Hence, it has been proposed that the antioxidant activity of orally or parenterally administered phycocyanin reflects, at least in large part, the ability of phycocyanobilin to mimic the physiological antioxidant activity of free bilirubin [56]. In aggregate, these considerations suggest that oral administration of spirulina, phycocyanin, or PhyCB-enriched spirulina extracts may have potential for slowing the expansion of osteolytic bone metastases that is driven by LPA generation. Although few studies to date have evaluated the impact of dietary spirulina on cancer progression in rodents, one recent study reported a $60 \%$ reduction in tumor growth rate when nude mice transplanted with a human pancreatic adenocarcinoma were fed a spirulina-enriched diet [59] - likely reflecting a role for constitutive NADPH oxidase activation in driving proliferation and promoting survival of this cancer [60-63].

Additionally, it is known that, in relatively high doses, statins can suppress activation of certain NADPH oxidase complexes by antagonizing the isoprenylation of Rac1 [64-66]. This may explain why, in mice injected with the MDA-MB-231 mammary cancer cell line, concurrent simvastatin treatment notably decreased the areas of osteolysis induced by bone metastases [67]. Nonetheless, statins can influence cellular function in numerous ways, and other mechanisms conceivably could have played a role in this effect.

\section{Complementary Measures for Suppressing Osteolysis}

Such measures could presumably be used in tandem with anti-osteolytic drugs-bisphosphonates and monoclonal antibodies targeting RANKL (e.g., denosumab)—currently used to slow growth of osteolytic bone metastases [68]. These can provide important pain relief, likely reflecting a role for acid production during osteolysis in triggering pain [69-72]. A meta-analysis of placebo-controlled trials with zoledronic acid found that, in cancer patients with rapid bone turnover at baseline 
(NTX > $100 \mathrm{nmol} / \mathrm{mmol}$ creatine in urine), use of zoledronic acid was associated with a $31 \%$ reduction in mortality risk [73]. Radium-223, although not directly anti-osteolytic, suppresses expansion of bone metastases by killing cancer cells resident in bone [74]. Platelet stabilizing agents have potential for diminishing the production of LPA in the microenvironment of cancer cells [6]. In this regard, an analysis of multi-center controlled trials assessing the effects of daily low-dose aspirin has found that such therapy decreases risk for metastasis formation in patients with pre-existing cancer [75]. This study did not report separately on bone metastases. A more recent meta-analysis confirms this finding [76].

A diet rich in omega-3 fatty acids may also have potential for suppressing cancer-induced osteolysis. Epidemiology has linked increased omega-3 intake to increased bone density [77-79]. In ovariectomized rats, diets high in flaxseed or fish oil favorably impact bone density by inhibiting osteolysis [80-83]. Moreover, in transgenic (fat-1) mice capable of converting omega-6 fats to omega-3s, the adverse impact of ovariectomy on bone density is blunted [84]. Similarly, supplementation with flaxseed (30 g daily) was found to decrease serum levels of the osteolysis marker NTx in healthy humans; a marker for bone formation was not changed [85]. In postmenopausal breast cancer survivors receiving aromatase inhibitor therapy, $4 \mathrm{~g}$ daily of fish omega-3s (EPA+DHA) likewise inhibited osteolysis [86]. In vitro, RANKL-stimulated conversion of monocytes to osteoclasts is inhibited by DHA and, intriguingly, arachidonic acid as well [87-90]. These findings may be rationalized by the recent discovery that DHA, arachidonic acid, and alpha-linolenic acid act as ligands for the farnesoid $X$ receptor (FXR), with binding affinities in the low micromolar range; they also promote the transcription of some but not all gene targets of FXR. FXR agonists have been shown to oppose osteoclastogenesis in vitro [91,92]. The possibility that ample intakes of flaxseed or fish oil could counter cancer-induced osteolysis via FXR agonism merits study in rodents. A diet rich in fish oil or in DHA per se inhibits the formation of bone metastases in nude mice given intracardiac injections of MDA-MB-231 breast cancer cells; to what extent suppression of metastatic seeding in the bone contributes to this effect is not clear [93,94]. In addition to its anti-osteolytic potential, ample intakes of flaxseed can exert anti-proliferative effects on some breast and prostate cancers-cancers known for their propensity to metastasize to bone $[95,96]$. This anti-proliferative effect has been documented clinically in patients with pre-surgical breast or prostate cancer asked to ingest $30 \mathrm{~g}$ of flaxseed daily $[97,98]$.

It should be noted that basal production of IL-8 is elevated in many cancers that are osteotrophic, and, not surprisingly, such cancers are prone to induce osteolytic metastases [99-101]. In women with breast cancer, plasma levels of IL-8 were found to be about twice as high in women who had bone metastases, as compared to women without such metastases; in addition, within the whole group, IL-8 levels correlated strongly and positively with serum levels of the osteolysis marker NTx [101]. When nude mice received intra-tibial injections of a breast cancer cell line producing ample amounts of IL-8, all of the mice developed large osteolytic bone lesions; when such mice in addition were treated with an IL-8-neutralizing monoclonal antibody, 83\% of the mice remained free of osteolytic lesions [101]. Hence, IL-8-targeting monoclonal antibodies may have potential as a clinical strategy for controlling osteolytic bone metastases.

\section{Conclusions}

In cancers prone to metastasize to bone, generation of LPA in the microenvironment of cancer cells can boost their capacity to stimulate osteolysis, thereby enabling the expansion of bone metastases. This mechanism is now suspected to play a key role in the spread of many osteotropic cancers. An analysis of the signaling mechanisms whereby LPA evokes this effect-including downstream activation of TGF-beta liberated from bone matrix - reveals at least three points (downstream from LPA, RANKL, and TGF-beta receptors) at which stimulation of NADPH oxidase activity plays a mediating role. Hence, measures which can safely down-regulate NADPH oxidase activation or activity may often have utility for slowing the expansion of bone metastases. By mimicking the physiological antioxidant role of free bilirubin, the PhyCB chromophore of spirulina may have potential as a nutraceutical 
inhibitor of NAPDH oxidase activity. High-dose statins likewise can inhibit NAPDH oxidase activity, by suppressing Rac isoprenylation. These considerations suggest that dietary administration of spirulina or of PhyCB-enriched spirulina extracts should be studied in rodent models of osteolytic bone metastases. Simvastatin has already demonstrated an anti-osteolytic effect in nude mice bearing human breast cancer. These measures, if proven to have efficacy, likely could be used to complement currently employed strategies for controlling bone metastases, such as bisphosphonates, denosumab, and radium-223. Platelet-stabilizing agents, omega-3 fats, and monoclonal antibodies targeting IL-8 may also have anti-osteolytic potential in oncology.

Author Contributions: Mark McCarty conceived and wrote the original draft; James DiNicolantonio provided additional insights that were then added to the manuscripts.

Conflicts of Interest: Mark McCarty is co-inventor and co-owner of a U.S. patent on nutraceutical uses of spirulina extracts enriched in phycocyanobilin oligopeptides. James DiNicolantonio has no conflicts to declare.

\section{References}

1. Peyruchaud, O.; LeBlanc, R.; David, M. Pleiotropic activity of lysophosphatidic acid in bone metastasis. Biochim. Biophys. Acta 2013, 1,99-104. [CrossRef] [PubMed]

2. Choi, J.W.; Herr, D.R.; Noguchi, K.; Yung, Y.C.; Lee, C.W.; Mutoh, T.; Lin, M.E.; Teo, S.T.; Park, K.E.; Mosleyet, A.N.; et al. LPA receptors: Subtypes and biological actions. Annu. Rev. Pharmacol. Toxicol. 2010, 50, 157-186. [CrossRef] [PubMed]

3. An, S.; Bleu, T.; Hallmark, O.G.; Goetzl, E.J. Characterization of a novel subtype of human G protein-coupled receptor for lysophosphatidic acid. J. Biol. Chem. 1998, 3, 147906-147910. [CrossRef]

4. LeBlanc, R.; Peyruchaud, O. New insights into the autotaxin/LPA axis in cancer development and metastasis. Exp. Cell Res. 2015, 2, 183-189. [CrossRef] [PubMed]

5. Liu, S.; Umezu-Goto, M.; Murph, M.; Lu, Y.L.; Liu, W.B.; Zhang, F.; Yu, S.X.; Stephens, L.C.; Cui, X.J.; Murrow, G.; et al. Expression of autotaxin and lysophosphatidic acid receptors increases mammary tumorigenesis, invasion, and metastases. Cancer Cell 2009, 6, 539-550. [CrossRef] [PubMed]

6. Boucharaba, A.; Serre, C.M.; Gres, S.; Saulnier-Blache, J.S.; Bordet, J.C.; Guglielmi, J.; Clézardin, P.; Peyruchaud, O. Platelet-derived lysophosphatidic acid supports the progression of osteolytic bone metastases in breast cancer. J. Clin. Investig. 2004, 114, 121714-121725. [CrossRef]

7. Aoki, J.; Taira, A.; Takanezawa, Y.; Kishi, Y.; Hama, K.; Kishimoto, T.; Mizuno, K.; Saku, K.; Taguchi, K.; Arai, H. Serum lysophosphatidic acid is produced through diverse phospholipase pathways. J. Biol. Chem. 2002, 50, 48737-48744. [CrossRef] [PubMed]

8. Umezu-Goto, M.; Kishi, Y.; Taira, A.; Hama, K.; Dohmae, N.; Takio, K.; Yamori, T.; Mills, G.B.; Inoue, K.; Aoki1, J.; et al. Autotaxin has lysophospholipase D activity leading to tumor cell growth and motility by lysophosphatidic acid production. J. Cell Biol. 2002, 158, 227-233. [CrossRef] [PubMed]

9. David, M.; Wannecq, E.; Descotes, F.; Jansen, S.; Deux, B.; Ribeiro, J.; Serre, C.M.; Grès, S.; Bendriss-Vermare, N.; Bollen, M.; et al. Cancer cell expression of autotaxin controls bone metastasis formation in mouse through lysophosphatidic acid-dependent activation of osteoclasts. PLoS ONE 2010, 5. [CrossRef] [PubMed]

10. Nouh, M.A.; Wu, X.X.; Okazoe, H.; Tsunemori, H.; Haba, R.; Abou-Zeid, A.M.M.; Saleem, M.D.; Inui, M.; Sugimoto, M.; Aoki, J.; et al. Expression of autotoxin and acylglycerol kinase in prostate cancer: Association with cancer development and progression. Cancer Sci. 2009, 100, 1631-1638. [CrossRef] [PubMed]

11. Bektas, M.; Payne, S.G.; Liu, H.; Goparaju, S.; Milstien, S.; Spiegel, S. A novel acylglycerol kinase that produces lysophosphatidic acid modulates cross talk with EGFR in prostate cancer cells. J. Cell Biol. 2005, 169, 801-811. [CrossRef] [PubMed]

12. Hwang, Y.S.; Hodge, J.C.; Sivapurapu, N.; Lindholm, P.F. Lysophosphatidic acid stimulates PC-3 prostate cancer cell Matrigel invasion through activation of RhoA and NF-kappaB activity. Mol. Carcinog. 2006, 45, 518-529. [CrossRef] [PubMed]

13. Hwang, Y.S.; Lee, J.; Zhang, X.; Lindholm, P.F. Lysophosphatidic acid activates the RhoA and NF-kappaB through $\mathrm{Akt} / \mathrm{I} \kappa \mathrm{B} \alpha$ signaling and promotes prostate cancer invasion and progression by enhancing functional invadopodia formation. Tumor Biol. 2016, 37, 6775-6785. [CrossRef] [PubMed] 
14. Kue, P.F.; Taub, J.S.; Harrington, L.B.; Polakiewicz, R.D.; Ullrich, A.; Daaka, Y. Lysophosphatidic acid-regulated mitogenic ERK signaling in androgen-insensitive prostate cancer PC-3 cells. Int. J. Cancer 2002, 102, 572-529. [CrossRef] [PubMed]

15. Fang, X.; Yu, S.; Bast, R.C.; Liu, S.Y.; Xu, H.J.; Hu, S.X.; LaPushin, R.; Claret, F.X.; Aggarwal\|, B.B.; Lu, Y.L.; et al. Mechanisms for lysophosphatidic acid-induced cytokine production in ovarian cancer cells. J. Biol. Chem. 2004, 279, 9653-9661. [CrossRef] [PubMed]

16. Lindholm, P.F.; Hwang, Y.S. LPA increases tumor growth and bone destruction through enhancement of osteoclastogenic cytokines. Anticancer Res. 2016, 36, 61-70. [PubMed]

17. Weilbaecher, K.N.; Guise, T.A.; McCauley, L.K. Cancer to bone: A fatal attraction. Nat. Rev. Cancer 2011, 11, 411-425. [CrossRef] [PubMed]

18. Mundy, G.R. Metastasis to bone: Causes, consequences and therapeutic opportunities. Nat. Rev. Cancer 2002, 2, 584-593. [CrossRef] [PubMed]

19. Saunders, J.A.; Rogers, L.C.; Klomsiri, C.; Poole, L.B.; Daniel, L.W. Reactive oxygen species mediate lysophosphatidic acid induced signaling in ovarian cancer cells. Free Radic. Biol. Med. 2010, 49, 2058-2067. [CrossRef] [PubMed]

20. Klomsiri, C.; Rogers, L.C.; Soito, L.; McCauleyb, A.K.; Kingc, S.B.; Nelsona, K.J.; Poolea, L.B.; Daniela, L.W. Endosomal $\mathrm{H}_{2} \mathrm{O}_{2}$ production leads to localized cysteine sulfenic acid formation on proteins during lysophosphatidic acid-mediated cell signaling. Free Radic. Biol. Med. 2014, 71, 49-60. [CrossRef] [PubMed]

21. Lin, C.C.; Lin, C.E.; Lin, Y.C.; Ju, T.K.; Huang, Y.L.; Lee, S.M.; Chen, J.H.; Lee, H. Lysophosphatidic acid induces reactive oxygen species generation by activating protein kinase $\mathrm{C}$ in PC-3 human prostate cancer cells. Biochem. Biophys. Res. Commun. 2013, 440, 564-569. [CrossRef] [PubMed]

22. Lee, N.K.; Choi, Y.G.; Baik, J.Y.; Han, S.Y.; Jeong, D.W.; Bae, Y.S.; Kim, N.; Lee, S.Y. A crucial role for reactive oxygen species in RANKL-induced osteoclast differentiation. Blood 2005, 106, 852-859. [CrossRef] [PubMed]

23. Sasaki, H.; Yamamoto, H.; Tominaga, K.; Masuda, K.; Kawai, T.; Teshima-Kondo, S.; Rokutan, K. NADPH oxidase-derived reactive oxygen species are essential for differentiation of a mouse macrophage cell line (RAW264.7) into osteoclasts. J. Med. Investig. 2009, 56, 33-41. [CrossRef] [PubMed]

24. Sasaki, H.; Yamamoto, H.; Tominaga, K.; Masuda, K.; Kawai, T.; Teshima-Kondo, S.; Matsuno, K.; Yabe-Nishimura, C.; Rokutan, K. Receptor activator of nuclear factor-kappaB ligand-induced mouse osteoclast differentiation is associated with switching between NADPH oxidase homologues. Free Radic. Biol. Med. 2009, 47, 189-199. [CrossRef] [PubMed]

25. Goettsch, C.; Babelova, A.; Trummer, O.; Erben, R.G.; Rauner, M.; Rammelt, S.; Weissmann, N.; Weinberger, V.; Benkhoff, S.; Kampschulte, M.; et al. NADPH oxidase 4 limits bone mass by promoting osteoclastogenesis. J. Clin. Investig. 2013, 123, 4731-4738. [CrossRef] [PubMed]

26. Kiriyama, T.; Gillespie, M.T.; Glatz, J.A.; Fukumoto, S.; Moseley, J.M.; Martin, T.J. Transforming growth factor beta stimulation of parathyroid hormone-related protein (PTHrP): A paracrine regulator? Mol. Cell Endocrinol. 1993, 92, 55-62. [CrossRef]

27. Yin, J.J.; Selander, K.; Chirgwin, J.M.; Dallas, M.; Grubbs, B.G.; Wieser, R.; Massagué, J.; Mundy, G.R.; Guise, T.A. TGF-beta signaling blockade inhibits PTHrP secretion by breast cancer cells and bone metastases development. J. Clin. Investig. 1999, 103, 197-206. [CrossRef] [PubMed]

28. Merryman, J.I.; DeWille, J.W.; Werkmeister, J.R.; Capen, C.C.; Rosol, T.J. Effects of transforming growth factor-beta on parathyroid hormone-related protein production and ribonucleic acid expression by a squamous carcinoma cell line in vitro. Endocrinology 1994, 134, 2424-2430. [CrossRef] [PubMed]

29. Lindemann, R.K.; Ballschmieter, P.; Nordheim, A.; Dittmer, J. Transforming growth factor beta regulates parathyroid hormone-related protein expression in MDA-MB-231 breast cancer cells through a novel Smad/Ets synergism. J. Biol. Chem. 2001, 276, 46661-46670. [CrossRef] [PubMed]

30. Kakonen, S.M.; Selander, K.S.; Chirgwin, J.M.; Yin, J.J.; Burns, S.; Rankin, W.A.; Grubbs, B.G.; Dallas, M.; Cui, Y.; Guise, T.A. Transforming growth factor-beta stimulates parathyroid hormone-related protein and osteolytic metastases via Smad and mitogen-activated protein kinase signaling pathways. J. Biol. Chem. 2002, 277, 24571-24578. [CrossRef] [PubMed]

31. Thomas, R.J.; Guise, T.A.; Yin, J.J.; Elliott, J.; Horwood, N.J.; Martin, T.J.; Gillespie, M.T. Breast cancer cells interact with osteoblasts to support osteoclast formation. Endocrinology 1999, 140, 4451-4458. [CrossRef] [PubMed] 
32. Liao, J.; McCauley, L.K. Skeletal metastasis: Established and emerging roles of parathyroid hormone related protein (PTHrP). Cancer Metastasis Rev. 2006, 25, 559-571. [CrossRef] [PubMed]

33. Kuo, P.L.; Liao, S.H.; Hung, J.Y.; Huang, M.S.; Hsu, Y.L. MicroRNA-33a functions as a bone metastasis suppressor in lung cancer by targeting parathyroid hormone related protein. Biochim. Biophys. Acta 2013, 6, 3756-3766. [CrossRef] [PubMed]

34. Park, H.J.; Baek, K.; Baek, J.H.; Kim, H.R. The cooperation of CREB and NFAT is required for PTHrP-induced RANKL expression in mouse osteoblastic cells. J. Cell Physiol. 2015, 230, 667-679. [CrossRef] [PubMed]

35. Hu, T.; RamachandraRao, S.P.; Siva, S.; Valancius, C.; Zhu, Y.Q.; Mahadev, K.; Toh, I.; Goldstein, B.J.; Woolkalis, M.; Sharmaet, K. Reactive oxygen species production via NADPH oxidase mediates TGF-beta-induced cytoskeletal alterations in endothelial cells. Am. J. Physiol. Renal. Physiol. 2005, 289, F816-F825. [CrossRef] [PubMed]

36. Michaeloudes, C.; Sukkar, M.B.; Khorasani, N.M.; Bhavsar, P.K.; Chung, K.F. TGF-beta regulates Nox4, MnSOD and catalase expression, and IL-6 release in airway smooth muscle cells. Am. J. Physiol. Lung Cell Mol. Physiol. 2011, 300, L295-L304. [CrossRef] [PubMed]

37. Sturrock, A.; Cahill, B.; Norman, K.; Huecksteadt, T.P.; Hill, K.; Sanders, K.; Karwande, S.V.; Stringham, J.C.; Bull, D.A.; Gleichet, M.; et al. Transforming growth factor-beta1 induces Nox4 NAD(P)H oxidase and reactive oxygen species-dependent proliferation in human pulmonary artery smooth muscle cells. Am. J. Physiol. Lung Cell Mol. Physiol. 2006, 290, L661-L673. [CrossRef] [PubMed]

38. Jiang, F.; Liu, G.S.; Dusting, G.J.; Chan, E.C. NADPH oxidase-dependent redox signaling in TGF-beta-mediated fibrotic responses. Redox Biol. 2014, 2, 267-272. [CrossRef] [PubMed]

39. Liu, R.M.; Choi, J.; Wu, J.H.; Kimberly, A.; Pravia, G.; Lewis, K.M.; Brand, J.D.; Mochel, N.S.R.; Krzywanski, D.M.; Lambeth, J.D.; et al. Oxidative modification of nuclear mitogen-activated protein kinase phosphatase 1 is involved in transforming growth factor beta1-induced expression of plasminogen activator inhibitor 1 in fibroblasts. J. Biol. Chem. 2010, 285, 16239-16247. [CrossRef] [PubMed]

40. Martin-Garrido, A.; Brown, D.I.; Lyle, A.N.; Dikalova, A.; Seidel-Rogol, B.; Lassègue, B.; Martín, A.S.; Griendling, K.K. NADPH oxidase 4 mediates TGF-beta-induced smooth muscle alpha-actin via p38MAPK and serum response factor. Free Radic. Biol. Med. 2011, 50, 354-362. [CrossRef] [PubMed]

41. Ikeda, R.; Ishii, K.; Hoshikawa, Y.; Azumi, J.; Arakaki, Y.; Yasui, T.; Matsuura, S.; Matsumi, Y.; Kono, Y.; Mizuta, Y.; et al. Reactive oxygen species and NADPH oxidase 4 induced by transforming growth factor beta1 are the therapeutic targets of polyenylphosphatidylcholine in the suppression of human hepatic stellate cell activation. Inflamm. Res. 2011, 60, 597-604. [CrossRef] [PubMed]

42. Yan, F.; Wang, Y.; Wu, X.; Peshavariya, H.M.; Dusting, G.J.; Zhang, M.; Jiang, F. Nox4 and redox signaling mediate TGF-beta-induced endothelial cell apoptosis and phenotypic switch. Cell Death Dis. 2014, 5. [CrossRef] [PubMed]

43. Lanone, S.; Bloc, S.; Foresti, R.; Almolki, A.; Taille, C.; Callebert, J.; Conti, M.; Goven, D.; Aubier, M.; Dureuil, B.; et al. Bilirubin decreases nos2 expression via inhibition of NAD(P)H oxidase: implications for protection against endotoxic shock in rats. FASEB J. 2005, 19, 1890-1892. [CrossRef] [PubMed]

44. Matsumoto, H.; Ishikawa, K.; Itabe, H.; Maruyama, Y. Carbon monoxide and bilirubin from heme oxygenase-1 suppresses reactive oxygen species generation and plasminogen activator inhibitor-1 induction. Mol. Cell Biochem. 2006, 291, 21-28. [CrossRef] [PubMed]

45. Jiang, F.; Roberts, S.J.; Datla, S.; Dusting, G.J. NO modulates NADPH oxidase function via heme oxygenase-1 in human endothelial cells. Hypertension 2006, 48, 950-957. [CrossRef] [PubMed]

46. Datla, S.R.; Dusting, G.J.; Mori, T.A.; Taylor, C.J.; Croft, K.D.; Jiang, F. Induction of heme oxygenase-1 in vivo suppresses NADPH oxidase derived oxidative stress. Hypertension 2007, 50, 636-642. [CrossRef] [PubMed]

47. Basuroy, S.; Bhattacharya, S.; Leffler, C.W.; Parfenova, H. Nox4 NADPH oxidase mediates oxidative stress and apoptosis caused by TNF-alpha in cerebral vascular endothelial cells. Am. J. Physiol. Cell Physiol. 2009, 296, C422-C432. [CrossRef] [PubMed]

48. Vitek, L. The role of bilirubin in diabetes, metabolic syndrome, and cardiovascular diseases. Front Pharmacol. 2012, 3. [CrossRef] [PubMed]

49. Temme, E.H.; Zhang, J.; Schouten, E.G.; Kesteloot, H. Serum bilirubin and 10-year mortality risk in a Belgian population. Cancer Causes Control 2001, 12, 887-894. [CrossRef] [PubMed]

50. Horsfall, L.J.; Nazareth, I.; Petersen, I. Cardiovascular events as a function of serum bilirubin levels in a large, statin-treated cohort. Circulation 2012, 126, 2556-2564. [CrossRef] [PubMed] 
51. Horsfall, L.J.; Rait, G.; Walters, K.; Swallow, D.M.; Pereira, S.P.; Nazareth, I.; Petersen, I. Serum bilirubin and risk of respiratory disease and death. JAMA 2011, 305, 691-697. [CrossRef] [PubMed]

52. Wagner, K.H.; Wallner, M.; Molzer, C.; Gazzin, S.; Bulmer, A.C.; Tiribelli, C.; Viteket, L. Looking to the horizon: The role of bilirubin in the development and prevention of age-related chronic diseases. Clin. Sci. 2015, 129, 1-25. [CrossRef] [PubMed]

53. McCarty, M.F. “Iatrogenic Gilbert syndrome”-A strategy for reducing vascular and cancer risk by increasing plasma unconjugated bilirubin. Med. Hypotheses 2007, 69, 974-994. [CrossRef] [PubMed]

54. Horsfall, L.J.; Nazareth, I.; Pereira, S.P.; Petersen, I. Gilbert's syndrome and the risk of death: A population-based cohort study. J. Gastroenterol. Hepatol. 2013, 28, 1643-1647. [CrossRef] [PubMed]

55. Romay, C.; Gonzalez, R.; Ledon, N.; Remirez, D.; Rimbau, V. C-phycocyanin: A biliprotein with antioxidant, anti-inflammatory and neuroprotective effects. Curr. Protein Pept. Sci. 2003, 4, 207-216. [CrossRef] [PubMed]

56. McCarty, M.F. Clinical potential of Spirulina as a source of phycocyanobilin. J. Med. Food 2007, 10, 566-570. [CrossRef] [PubMed]

57. Terry, M.J.; Maines, M.D.; Lagarias, J.C. Inactivation of phytochrome- and phycobiliprotein-chromophore precursors by rat liver biliverdin reductase. J. Biol. Chem. 1993, 268, 26099-26106. [PubMed]

58. Zheng, J.; Inoguchi, T.; Sasaki, S.; Maeda, Y.; McCarty, M.F.; Fujii, M.; Ikeda, N.; Kobayashi, K.; Sonoda, N.; Takayanagiet, R. Phycocyanin and phycocyanobilin from spirulina platensis protect against diabetic nephropathy by inhibiting oxidative stress. Am. J. Physiol. Regul. Integr. Comp. Physiol. 2012, 304, R110-R120. [CrossRef] [PubMed]

59. Pari, L.; Murugavel, P. Protective effect of alpha-lipoic acid against chloroquine-induced hepatotoxicity in rats. J. Appl. Toxicol. 2004, 24, 21-26. [CrossRef] [PubMed]

60. Johnsen-Soriano, S.; Garcia-Pous, M.; Arnal, E.; Sancho-Telloet, M.; Garcia-Delpech, S.; Miranda, M.; Bosch-Morell, F.; Diaz-Llopis, M.; Navea, A.; Romero, F.J. Early lipoic acid intake protects retina of diabetic mice. Free Radic. Res. 2008, 42, 613-617. [CrossRef] [PubMed]

61. Kojima, M.; Sun, L.; Hata, I.; Sakamoto, Y.; Sasaki, H.; Sasaki, K. Efficacy of alpha-lipoic acid against diabetic cataract in rat. Jpn. J. Ophthalmol. 2007, 51, 10-13. [CrossRef] [PubMed]

62. Lin, J.; Bierhaus, A.; Bugert, P.; Dietrich, N.; Feng, J.; Hagen, F.V.; Nawroth, P.; Brownlee, M.; Hammes, H.P. Effect of R-(+)-alpha-lipoic acid on experimental diabetic retinopathy. Diabetologia 2006, 49, 1089-1096. [CrossRef] [PubMed]

63. Lateef, H.; Aslam, M.N.; Stevens, M.J.; Varani, J. Pretreatment of diabetic rats with lipoic acid improves healing of subsequently-induced abrasion wounds. Arch. Dermatol. Res. 2005, 297, 75-83. [CrossRef] [PubMed]

64. Wagner, A.H.; Kohler, T.; Ruckschloss, U.; Just, I.; Hecker, M. Improvement of nitric oxide-dependent vasodilatation by HMG-CoA reductase inhibitors through attenuation of endothelial superoxide anion formation. Arterioscler. Thromb. Vasc. Biol. 2000, 20, 61-69. [CrossRef] [PubMed]

65. Endres, M.; Laufs, U. Effects of statins on endothelium and signaling mechanisms. Stroke 2004, 35, $2708-2711$. [CrossRef] [PubMed]

66. Adam, O.; Laufs, U. Rac1-mediated effects of HMG-CoA reductase inhibitors (statins) in cardiovascular disease. Antioxid. Redox Signal. 2014, 20, 1238-1250. [CrossRef] [PubMed]

67. Mandal, C.C.; Ghosh-Choudhury, N.; Yoneda, T.; Choudhury, G.G.; Ghosh-Choudhury, N. Simvastatin prevents skeletal metastasis of breast cancer by an antagonistic interplay between p53 and CD44. J. Biol. Chem. 2011, 286, 11314-11327. [CrossRef] [PubMed]

68. El-Amm, J.; Aragon-Ching, J.B. Targeting bone metastases in metastatic castration-resistant prostate cancer. Clin. Med. Insights Oncol. 2016, 10, 11-19. [PubMed]

69. Coleman, R.E.; Guise, T.A.; Lipton, A.; Roodman, G.D.; Berenson, J.R.; Body, J.J.; Boyce, B.F.; Calvi, L.M.; Hadji, P.; McCloskey, E.V.; et al. Advancing treatment for metastatic bone cancer: Consensus recommendations from the Second Cambridge Conference. Clin. Cancer Res. 2008, 14, 6387-6395. [CrossRef] [PubMed]

70. Honore, P.; Luger, N.M.; Sabino, M.A.; Schwei, M.J.; Rogers, S.D.; Mach, D.B.; O'keefe, P.F.; Ramnaraine, M.L.; Clohisy, D.R.; Mantyhet, P.W. Osteoprotegerin blocks bone cancer-induced skeletal destruction, skeletal pain and pain-related neurochemical reorganization of the spinal cord. Nat. Med. 2000, 6, 521-528. [PubMed] 
71. Nakanishi, M.; Hata, K.; Nagayama, T.; Sakurai, T.; Nishisho, T.; Wakabayashi, H.; Hiraga, T.; Ebisu, S.; Yoneda, T. Acid activation of Trpv1 leads to an up-regulation of calcitonin gene-related peptide expression in dorsal root ganglion neurons via the CaMK-CREB cascade: A potential mechanism of inflammatory pain. Mol. Biol. Cell 2010, 21, 2568-2577. [CrossRef] [PubMed]

72. Yoneda, T.; Hiasa, M.; Nagata, Y.; Okui, T.; White, F. Contribution of acidic extracellular microenvironment of cancer-colonized bone to bone pain. Biochim. Biophys. Acta 2015, 10, 2677-2684. [CrossRef] [PubMed]

73. Coleman, R.E.; Lipton, A.; Costa, L.; Cook, R.J.; Lee, K.A.; Saad, F.; Brown, J.E.; Terpos, E.; Major, P.P.; Kohno, N.; et al. Possible survival benefits from zoledronic acid treatment in patients with bone metastases from solid tumors and poor prognostic features-An exploratory analysis of placebo-controlled trials. J. Bone Oncol. 2013, 2, 70-76. [CrossRef] [PubMed]

74. Baydas, G.; Donder, E.; Kiliboz, M.; Sonkaya, E.; Tuzcu, M.; Yasar, A.; Nedzvetskii, V.S. Neuroprotection by alpha-lipoic acid in streptozotocin-induced diabetes. Biochemistry 2004, 69, 1001-1005. [PubMed]

75. Rothwell, P.M.; Wilson, M.; Price, J.F.; Belch, J.F.; Meade, T.W.; Mehta, Z. Effect of daily aspirin on risk of cancer metastasis: A study of incident cancers during randomized controlled trials. Lancet 2012, 379, 1591-1601. [CrossRef]

76. Elwood, P.C.; Morgan, G.; Pickering, J.E.; Galante, J.; Weightman, A.L.; Morris, D.; Kelson, M.; Dolwani, S. Aspirin in the treatment of cancer: Reductions in metastatic spread and in mortality: A systematic review and meta-analyses of published studies. PLOS ONE 2016, 11. [CrossRef] [PubMed]

77. Hogstrom, M.; Nordstrom, P.; Nordstrom, A. n-3 Fatty acids are positively associated with peak bone mineral density and bone accrual in healthy men: The $\mathrm{NO}_{2}$ study. Am. J. Clin. Nutr. 2007, 85, 803-807. [PubMed]

78. Rousseau, J.H.; Kleppinger, A.; Kenny, A.M. Self-reported dietary intake of omega-3 fatty acids and association with bone and lower extremity function. J. Am. Geriatr. Soc. 2009, 57, 1781-1788. [CrossRef] [PubMed]

79. Jarvinen, R.; Tuppurainen, M.; Erkkila, A.T.; Penttinen, P.; Kärkkäinen, M.; Salovaara, K.; Jurvelin, J.S.; Kröger, H. Associations of dietary polyunsaturated fatty acids with bone mineral density in elderly women. Eur. J. Clin. Nutr. 2012, 66, 496-503. [CrossRef] [PubMed]

80. Boulbaroud, S.; Mesfioui, A.; Arfaoui, A.; Ouichou, A.; el-Hessni, A. Preventive effects of flaxseed and sesame oil on bone loss in ovariectomized rats. Pak. J. Biol. Sci. 2008, 11, 1696-1701. [CrossRef] [PubMed]

81. Sacco, S.M.; Jiang, J.M.; Reza-Lopez, S.; Ma, D.W.; Thompson, L.U.; Ward, W.E. Flaxseed combined with low-dose estrogen therapy preserves bone tissue in ovariectomized rats. Menopause 2009, 16, 545-554. [CrossRef] [PubMed]

82. Sacco, S.M.; Chen, J.; Ganss, B.; Thompson, L.U.; Ward, W.E. Flaxseed enhances the beneficial effect of low-dose estrogen therapy at reducing bone turnover and preserving bone microarchitecture in ovariectomized rats. Appl. Physiol. Nutr. Metab. 2014, 39, 801-810. [CrossRef] [PubMed]

83. Nakanishi, A.; Iitsuka, N.; Tsukamoto, I. Fish oil suppresses bone resorption by inhibiting osteoclastogenesis through decreased expression of M-CSF, PU.1, MITF and RANK in ovariectomized rats. Mol. Med. Rep. 2013, 7, 1896-1903. [PubMed]

84. Rahman, M.M.; Bhattacharya, A.; Banu, J.; Kang, J.X.; Fernandes, G. Endogenous n-3 fatty acids protect ovariectomy induced bone loss by attenuating osteoclastogenesis. J. Cell Mol. Med. 2009, 13, 1833-1844. [CrossRef] [PubMed]

85. Griel, A.E.; Kris-Etherton, P.M.; Hilpert, K.F.; Zhao, G.; West, S.G.; Corwin, R.L. An increase in dietary n-3 fatty acids decreases a marker of bone resorption in humans. Nutr. J. 2007, 6. [CrossRef] [PubMed]

86. Hutchins-Wiese, H.L.; Picho, K.; Watkins, B.A.; Li, Y.; Tannanbum, S.; Claffey, K.; Kenny, A.M. High-dose eicosapentaenoic acid and docosahexaenoic acid supplementation reduces bone resorption in postmenopausal breast cancer survivors on aromatase inhibitors: A pilot study. Nutr. Cancer 2014, 66, 68-76. [CrossRef] [PubMed]

87. Rahman, M.M.; Bhattacharya, A.; Fernandes, G. Docosahexaenoic acid is more potent inhibitor of osteoclast differentiation in RAW 264.7 cells than eicosapentaenoic acid. J. Cell Physiol. 2008, 214, 201-209. [CrossRef] [PubMed] 
88. Akiyama, M.; Nakahama, K.; Morita, I. Impact of docosahexaenoic acid on gene expression during osteoclastogenesis in vitro-A comprehensive analysis. Nutrients 2013, 5, 3151-3162. [CrossRef] [PubMed]

89. Kasonga, A.E.; Deepak, V.; Kruger, M.C.; Coetzee, M. Arachidonic acid and docosahexaenoic acid suppress osteoclast formation and activity in human CD14+ monocytes, in vitro. PLoS ONE 2015, 10. [CrossRef] [PubMed]

90. Boeyens, J.C.; Deepak, V.; Chua, W.H.; Kruger, M.C.; Joubert, A.M.; Coetzee, M. Effects of omega3- and omega6-polyunsaturated fatty acids on RANKL-induced osteoclast differentiation of RAW264.7 cells: A comparative in vitro study. Nutrients 2014, 6, 2584-2601. [CrossRef] [PubMed]

91. Zhao, A.; Yu, J.; Lew, J.L.; Huang, L.; Wright, S.D.; Cui, J. Polyunsaturated fatty acids are FXR ligands and differentially regulate expression of FXR targets. DNA Cell Biol. 2004, 23, 519-526. [CrossRef] [PubMed]

92. Vanden Heuvel, J.P.; Belda, B.J.; Hannon, D.B.; Kris-Etherton, K.M.; Grieger, J.A.; Zhang, J.; Thompson, J.T. Mechanistic examination of walnuts in prevention of breast cancer. Nutr. Cancer 2012, 64, 1078-1086. [CrossRef] [PubMed]

93. Mandal, C.C.; Ghosh-Choudhury, T.; Yoneda, T.; Choudhury, G.G.; Ghosh-Choudhury, N. Fish oil prevents breast cancer cell metastasis to bone. Biochem. Biophys. Res. Commun. 2010, 402, 602-607. [CrossRef] [PubMed]

94. Rahman, M.M.; Veigas, J.M.; Williams, P.J.; Fernandes, G. DHA is a more potent inhibitor of breast cancer metastasis to bone and related osteolysis than EPA. Breast Cancer Res. Treat. 2013, 141, 341-352. [CrossRef] [PubMed]

95. Mason, J.K.; Thompson, L.U. Flaxseed and its lignan and oil components: Can they play a role in reducing the risk of and improving the treatment of breast cancer? Appl. Physiol. Nutr. Metab. 2014, 39, 663-678. [CrossRef] [PubMed]

96. Lin, X.; Gingrich, J.R.; Bao, W.; Li, J.; Haroon, Z.A.; Demark-Wahnefried, W. Effect of flaxseed supplementation on prostatic carcinoma in transgenic mice. Urology 2002, 60, 919-924. [CrossRef]

97. Thompson, L.U.; Chen, J.M.; Li, T.; Strasser-Weippl, K.; Goss, P.E. Dietary flaxseed alters tumor biological markers in postmenopausal breast cancer. Clin. Cancer Res. 2005, 11, 3828-3835. [CrossRef] [PubMed]

98. Demark-Wahnefried, W.; Polascik, T.J.; George, S.L.; Switzer, B.R.; Madden, J.F.; Ruffin, M.T., IV; Snyder, D.C.; Owzar, K.; Hars, V.; Albala, D.M.; et al. Flaxseed supplementation (not dietary fat restriction) reduces prostate cancer proliferation rates in men presurgery. Cancer Epidemiol. Biomarkers Prev. 2008, 17, 3577-3587. [CrossRef] [PubMed]

99. Bendre, M.S.; Gaddy-Kurten, D.; Mon-Foote, T.; Akel, N.S.; Skinner, R.A.; Nicholas, R.W.; Suva, L.J. Expression of interleukin 8 and not parathyroid hormone-related protein by human breast cancer cells correlates with bone metastasis in vivo. Cancer Res. 2002, 62, 5571-5579. [PubMed]

100. Bendre, M.S.; Montague, D.C.; Peery, T.; Akel, N.S.; Gaddy, D.; Suva, L.J. Interleukin-8 stimulation of osteoclastogenesis and bone resorption is a mechanism for the increased osteolysis of metastatic bone disease. Bone 2003, 33, 28-37. [CrossRef]

101. Kamalakar, A.; Bendre, M.S.; Washam, C.L.; Fowler, T.W.; Carver, A.; Dilley, J.D.; Bracey, J.W.; Akel, N.S.; Margulies, A.G.; Skinner, R.A.; et al. Circulating interleukin-8 levels explain breast cancer osteolysis in mice and humans. Bone 2014, 61, 176-185. [CrossRef] [PubMed]

(C) 2016 by the authors; licensee MDPI, Basel, Switzerland. This article is an open access article distributed under the terms and conditions of the Creative Commons Attribution (CC-BY) license (http://creativecommons.org/licenses/by/4.0/). 